\title{
Haladaptatus cibarius sp. nov., an extremely halophilic archaeon from seafood, and emended description of the genus Haladaptatus
}

Correspondence Jin-Woo Bae baejw@khu.ac.kr

\author{
Seong Woon Roh, Myung-Lip Lee and Jin-Woo Bae
}

\author{
Department of Life and Nanopharmaceutical Sciences and Department of Biology, Kyung Hee \\ University, Seoul 130-701, Republic of Korea
}

The genus Haladaptatus in the family Halobacteriaceae was first proposed by Savage et al. (2007) and currently comprises only one species, Haladaptatus paucihalophilus, which was isolated from a low-salt, sulfide- and sulfur-rich spring. It was reported that the colonies of Hap. paucihalophilus are pink and that the cells are Gramnegative and non-motile and have the phospholipids phosphatidylglycerol (PG), phosphatidylglycerol phosphate methyl ester (PGP-Me) and phosphatidylglycerol sulfate (PGS) (Savage et al., 2007). In a study of archaeal diversity in traditional salt-fermented seafood in Korea, the extremely halophilic archaea Natronococcus jeotgali (Roh et al., 2007a), Halalkalicoccus jeotgali (Roh et al., 2007b), Halorubrum cibi (Roh \& Bae, 2009) and Haloterrigena jeotgali (Roh et al., 2009) were proposed as novel species in the family Halobacteriaceae. Through further study of archaeal diversity in salt-fermented seafood that comprises fish or shellfish with lots of rock salt, we identified a novel strain, designated $\mathrm{D} 43^{\mathrm{T}}$, that was obtained from a salt-rich fermented seafood made from shellfish.

\footnotetext{
Abbreviations: PG, phosphatidylglycerol; PGP-Me, phosphatidylglycerol phosphate methyl ester; PGS, phosphatidylglycerol sulfate.

The GenBank/EMBL/DDBJ accession number for the 16S rRNA gene sequence from strain D43 ${ }^{\top}$ is EF660747.

A thin-layer chromatogram of the polar lipids in Haladaptatus species is available as a supplementary figure with the online version of this paper.
}

The salt-fermented seafood was purchased from a distributor of a commercially available brand in Korea. A sample ( $1 \mathrm{ml})$, obtained just after the pack was opened, was serially diluted and spread onto a complex medium (DSM medium 954) adjusted to $\mathrm{pH} 7.0$ [containing $\left(\mathrm{l}^{-1}\right) 5 \mathrm{~g}$ Casamino acids (Difco), $5 \mathrm{~g}$ yeast extract (Difco), $20 \mathrm{~g}$ $\mathrm{MgCl}_{2} \cdot 6 \mathrm{H}_{2} \mathrm{O}, 2 \mathrm{~g} \mathrm{KCl}, 12 \mathrm{~g}$ Tris base, $0.2 \mathrm{~g} \mathrm{CaCl}_{2} \cdot 2 \mathrm{H}_{2} \mathrm{O}$, $200 \mathrm{~g} \mathrm{NaCl}, 20 \mathrm{~g}$ agar], with antimicrobial compounds as described previously (Roh et al., 2007a). The plates were incubated at $37{ }^{\circ} \mathrm{C}$ for 1 month and a single colony was streaked at least three times on the halophile medium to obtain a pure culture. The characterization of strain D43 $3^{\mathrm{T}}$ was guided by the proposed minimal standards for describing extremely halophilic archaea (Oren et al., 1997). All tests were performed in triplicate unless stated otherwise. Cell morphology was examined by light microscopy (Eclipse 80i; Nikon) and motility was examined on semi-solid agar plates and using electron microscopy. Gram staining was performed using the standard staining method for haloarchaea as described by Dussault (1955). Cell lysis in distilled water was detected by microscopic examination. Optimal conditions for growth were determined in medium 954 with $0-30 \%(w / v) ~ \mathrm{NaCl}$ (at intervals of $5 \%$ ) and at $4,10,15,20,25,30,37,40,50$ and $60{ }^{\circ} \mathrm{C}$ and in halophilic medium [HMD; containing $\left(^{-1}\right) 20 \mathrm{~g} \mathrm{MgCl}_{2} .6 \mathrm{H}_{2} \mathrm{O}, 5 \mathrm{~g} \mathrm{~K}_{2} \mathrm{SO}_{4}, 0.1 \mathrm{~g} \mathrm{CaCl}_{2} .2 \mathrm{H}_{2} \mathrm{O}$, 0.1 g yeast extract, $0.5 \mathrm{~g} \mathrm{NH}_{4} \mathrm{Cl}, 0.05 \mathrm{~g} \mathrm{KH}_{2} \mathrm{PO}_{4}, 0.5 \mathrm{~g}$ Casamino acids as carbon source, $180 \mathrm{~g} \mathrm{NaCl}$; Savage et al., 
2007] at $\mathrm{pH} 3.0-11.0$ (at intervals of $1 \mathrm{pH}$ unit). The requirement for and minimal concentration of $\mathrm{Mg}^{2+}$ for growth were examined using medium 954 containing $0.01 \%$ yeast extract without $\mathrm{MgCl}_{2} \cdot 6 \mathrm{H}_{2} \mathrm{O}$ at different $\mathrm{Mg}^{2+}$ concentrations $(0,5,10,20,50,100,200$ and $500 \mathrm{mM}$ ). Standard phenotypic tests for nitrate reduction under aerobic conditions, indole formation, activity of oxidase and catalase and hydrolysis of casein, starch and urea were conducted as described by Gerhardt et al. (1994). Hydrolysis of gelatin and Tween 80 were tested simultaneously through the procedure of Gutierrez \& Gonzalez (1972). Utilization of sole carbon and energy sources as well as acid production was determined using HMD as described by Savage et al. (2007) with $20 \mathrm{mM}$ carbon source. Tests for anaerobic growth in the presence of $30 \mathrm{mM}$ nitrate, sulfate, thiosulfate or DMSO were performed in stopped tubes as described by Sehgal \& Gibbons (1960). Antibiotic sensitivity was performed using the diffusion agar method (Bauer et al., 1966 ) with the following antimicrobial compounds ( $\mu \mathrm{g}$ unless otherwise stated): ampicillin (10), anisomycin (30), aphidicolin (30), chloramphenicol (30), erythromycin (15), kanamycin (30), rifampicin (30), streptomycin (10) and polymycin B (300 UI).

Colonies of strain $\mathrm{D} 43^{\mathrm{T}}$ were pink and cells were Gramnegative-staining and motile on semi-solid agar medium. Strain $\mathrm{D} 43^{\mathrm{T}}$ was catalase- and oxidase-positive and did not reduce nitrate to nitrite under aerobic conditions. Lysis of cells and changes of cell-wall morphology were not detected in distilled water after 2 weeks and cells remained alive under these conditions. Detailed characteristics of strain $\mathrm{D} 43^{\mathrm{T}}$ are presented in the species description and compared with those of Hap. paucihalophilus $\mathrm{DX} 253^{\mathrm{T}}$ in Table 1.

Chromosomal DNA of strain D43 ${ }^{\mathrm{T}}$ and Hap. paucihalophilus KCTC $4006^{\mathrm{T}}$ was extracted and purified as described by
Sambrook et al. (1989) and the 16S rRNA gene sequence of strain $\mathrm{D} 43^{\mathrm{T}}$ was amplified by PCR using archaea-specific primer set 21F (5'-TTCCGGTTGATCCTGCCGGA-3') and 1492R ( $5^{\prime}$-GGYTACCTTGTTACGACTT-3'). Sequencing of the amplified gene fragments and assembly of the sequences were performed as described previously (Roh et al., 2008). Identification of phylogenetic neighbours and the calculation of pairwise sequence similarities were carried out by a BLAST search of GenBank (Altschul et al., 1997). Phylogenetic relationships between the isolate and phylogenetic neighbours were determined using MEGA 4.0 (Tamura et al., 2007) and PHYLIP software (Felsenstein, 2005). A distance matrix was determined using the two-parameter model of Kimura (1980). Phylogenetic trees were generated by three algorithms: neighbour joining (Saitou \& Nei, 1987), maximum parsimony (Kluge \& Farris, 1969) and maximum likelihood (Felsenstein, 1981). Bootstrap analysis to evaluate the stability of phylogenetic trees was achieved using a consensus tree from the neighbour-joining, maximum-parsimony and maximum-likelihood methods, based on 1000, 1000 and 100 replicates, respectively.

The nearly complete 16S rRNA gene sequence of strain

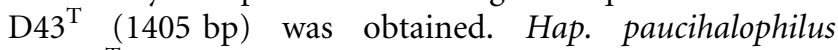
DX253 ${ }^{\mathrm{T}}$, as well as other uncharacterized strains isolated by Purdy et al. (2004), has two distinct 16S rRNA gene sequences; however, no multiple heterogeneous sequences were detected in strain $\mathrm{D} 43^{\mathrm{T}}$ through the cloning approach. Comparison of $16 \mathrm{~S}$ rRNA gene sequences indicated that the isolate is associated with the family Halobacteriaceae. Strain D43 ${ }^{\mathrm{T}}$ exhibited high $16 \mathrm{~S}$ rRNA gene sequence similarity with uncharacterized haloarchaeon strains RO1-28 (98.8\%) and RO1-22 (98.5\%), haloarchaeon clone W1 (96.1\%), Hap. paucihalophilus DX253 ${ }^{\mathrm{T}}$ (95.5 and 93.0\%), Hap. paucihalophilus GY252 (95.3 and $94.3 \%$ ) and other uncharacterized or uncultured

Table 1. Differentiating characteristics of strain $\mathrm{D} 43^{\top}$ and Hap. paucihalophilus $\mathrm{DX} 253^{\top}$

Data for Hap. paucihalophilus DX253 $3^{\mathrm{T}}$ were obtained in this study or taken from Savage et al. (2007).

\begin{tabular}{|c|c|c|}
\hline Characteristic & Strain $\mathrm{D} 43^{\mathrm{T}}$ & Hap. paucihalophilus DX253 ${ }^{\mathrm{T}}$ \\
\hline Isolation source & Salt-rich, fermented seafood & Low-salt, sulfide-rich spring \\
\hline Motility & + & - \\
\hline $\mathrm{NaCl}$ range (optimum) (\%) & $10-30(15)$ & $5-30(18)$ \\
\hline Temperature range (optimum) $\left({ }^{\circ} \mathrm{C}\right)$ & $15-50(37)$ & $25-45(30)$ \\
\hline \multicolumn{3}{|l|}{ Hydrolysis of: } \\
\hline Casein & - & + \\
\hline Starch & - & + \\
\hline \multicolumn{3}{|l|}{ Utilization of: } \\
\hline Citrate & - & + \\
\hline Lactose & + & - \\
\hline Mannitol & - & + \\
\hline \multicolumn{3}{|l|}{ Acid production from: } \\
\hline Fructose & - & + \\
\hline Mannitol & - & + \\
\hline DNA G $+C$ content $(\mathrm{mol} \%)$ & 56.5 & 60.5 \\
\hline
\end{tabular}


haloarchaeon strains (95.4\% or less). The isolate formed a clade with Hap. paucihalophilus, uncharacterized strains and uncultured haloarchaeon clones in phylogenetic trees based on 16S rRNA gene sequences, with high bootstrap values (Fig. 1), regardless of which tree-generating algorithm was used (data not shown). The molecular phylogenetic analyses supported the placement of strain $\mathrm{D} 43^{\mathrm{T}}$ in the genus Haladaptatus of the family Halobacteriaceae.

To determine the genetic distance between strain $\mathrm{D} 43^{\mathrm{T}}$ and Hap. paucihalophilus, a DNA-DNA hybridization experiment was performed with the modified method of Ezaki et al. (1989) as described previously (Roh et al., 2008). The mean DNA-DNA relatedness between strain $\mathrm{D} 43^{\mathrm{T}}$ and Hap. paucihalophilus KCTC $4006^{\mathrm{T}}$ was $25.8 \%$. DNA-DNA relatedness values below a threshold of $70 \%$ indicated that the isolate represents a distinct genospecies (Wayne et al., 1987). The $\mathrm{G}+\mathrm{C}$ content was determined by a fluorimetric method using SYBR Green and a real-time PCR thermocycler (Gonzalez \& Saiz-Jimenez, 2002) with the calibration references Haloterrigena thermotolerans $\mathrm{PR}^{\mathrm{T}}$ and Halorubrum tibetense AS $1.3239^{\mathrm{T}}$. The DNA $\mathrm{G}+\mathrm{C}$ content of strain $\mathrm{D} 43^{\mathrm{T}}$ was $56.5 \mathrm{~mol} \%$. The $\mathrm{G}+\mathrm{C}$ content of genomic DNA of Hap. paucihalophilus strains DX253 ${ }^{\mathrm{T}}$ and GY252 is $60.5 \mathrm{~mol} \%$ (Savage et al., 2007). Thus, the $\mathrm{G}+\mathrm{C}$ content of strain $\mathrm{D} 43^{\mathrm{T}}$ is relatively lower than the value reported previously for the genus Haladaptatus.

Polar lipids were extracted and detected with specific reagents (Dittmer \& Lester, 1964; Xin et al., 2000) sprayed on a Merck silica gel $60 \mathrm{~F}_{254}$ aluminium-backed plate, as described by Oren et al. (1996). The designations of all lipid spots were given according to Savage et al. (2007). The major lipids of strain $\mathrm{D} 43^{\mathrm{T}}$ comprised PG, PGP-Me and two unidentified glycolipids (Supplementary Fig. S1, available in IJSEM Online), in agreement with those reported for all strains of haloarchaea and Hap. paucihalophilus described by Savage et al. (2007); however, PGS was not detected. It is concluded that the presence of PGS is variable within the genus Haladaptatus.

Our polyphasic taxonomic study, including data from molecular phylogenetic analysis, DNA-DNA relatedness, genomic DNA G $+C$ content, polar lipid profile and physiological and biochemical tests, showed genotypic and phenotypic differences between the new isolate and Hap. paucihalophilus. On the basis of genetic, chemotaxonomic and phenotypic comparisons with previously described taxa, strain $\mathrm{D} 43^{\mathrm{T}}$ is affiliated with the genus Haladaptatus and represents a novel species in the genus Haladaptatus, for which the name Haladaptatus cibarius sp. nov. is proposed.

\section{Emended description of the genus Haladaptatus Savage et al. 2007}

The description is based on that given by Savage et al. (2007), with the following amendments. Cells contain PG, PGP-Me and two unidentified glycolipids. The presence of PGS is variable. The DNA G+C content is 56.5$60.5 \mathrm{~mol} \%$.

\section{Description of Haladaptatus cibarius sp. nov.}

Haladaptatus cibarius (ci.ba'ri.us. L. masc. adj. cibarius pertaining to or suitable for food).

Cells are aerobic, Gram-negative-staining cocci or coccobacilli with a diameter of $1.0 \mu \mathrm{m}$, motile with a single polar flagellum. The colonies are pink, circular with entire margins and $1.0 \mathrm{~mm}$ in diameter after 3 weeks of incubation on a complex agar medium (DSM medium 954) at $37{ }^{\circ} \mathrm{C}$. Growth occurs at $15-50{ }^{\circ} \mathrm{C}$ (optimum $37{ }^{\circ} \mathrm{C}$ ), in the presence of $10-30 \%(\mathrm{w} / \mathrm{v}) \mathrm{NaCl}$ (optimum $15 \%$ ) and at $\mathrm{pH}$ 6.0-8.0 (optimum $\mathrm{pH} 7.0$ ). $\mathrm{Mg}^{2+}$ is required for growth. The minimal $\mathrm{Mg}^{2+}$ concentration for growth and the $\mathrm{Mg}^{2+}$ concentration for optimal growth are 5 and $20 \mathrm{mM}$, respectively. Cell lysis does not occur in

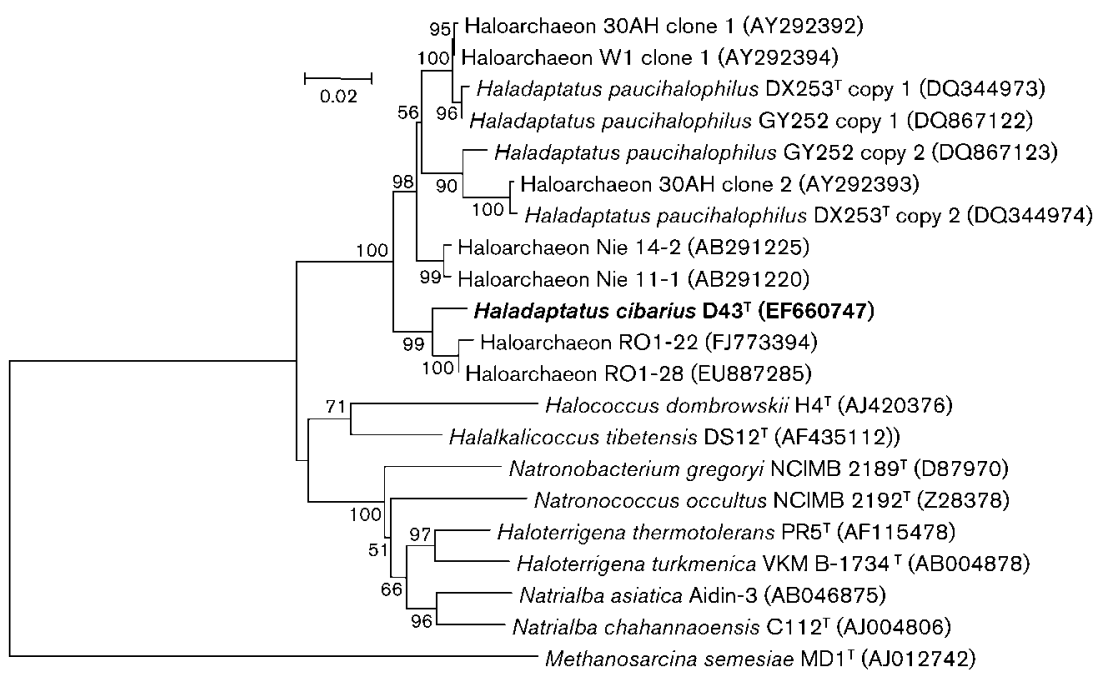

Fig. 1. Phylogenetic tree based on $16 \mathrm{~S}$ rRNA gene sequences generated using the neighbourjoining method. Bootstrap values ( $>50 \%$ ) based on 1000 replicates are shown as percentages at branch nodes. Methanosarcina semesiae $\mathrm{MD}^{\top}{ }^{\top}$ was used as an outgroup. Bar, 0.02 substitutions per nucleotide position. 
distilled water. Positive for catalase, oxidase and indole formation. Does not reduce nitrate to nitrite under aerobic conditions. Gelatin and Tween 80 are hydrolysed, but starch, casein and urea are not. Sucrose, D-fructose, Dglucose, lactose, formate and acetate are utilized as carbon and energy sources, but citrate and D-mannitol are not. Acid is produced from sucrose and D-glucose, but not from D-fructose, citrate, lactose, formate, acetate or D-mannitol. Anaerobic growth with nitrate, sulfate, thiosulfate or DMSO does not occur. Sensitive to anisomycin, aphidicolin, chloramphenicol and rifampicin, and resistant to ampicillin, erythromycin, kanamycin, streptomycin and polymycin B. The polar lipids are PG, PGP-Me and two unidentified glycolipids. The genomic DNA G + C content of the type strain is $56.5 \mathrm{~mol} \%$.

The type strain is $\mathrm{D} 43^{\mathrm{T}}\left(=\mathrm{DSM} 19505^{\mathrm{T}}=\mathrm{JCM} 15962^{\mathrm{T}}\right)$, which was isolated from Korean salt-fermented seafood made from shellfish.

\section{Acknowledgements}

We thank Dr J. P. Euzéby (Ecole Nationale Vétérinaire, France) for etymological advice. This work was supported by NMC0300837, the Environmental Biotechnology National Core Research Center (KOSEF: R15-2003-012-02002-0) and TDPAF (Technology Development Program for Agriculture and Forestry) of the Ministry for Agriculture, Forestry and Fisheries, Republic of Korea.

\section{References}

Altschul, S. F., Madden, T. L., Schaffer, A. A., Zhang, J., Zhang, Z., Miller, W. \& Lipman, D. J. (1997). Gapped BLAST and PSI-BLAST: a new generation of protein database search programs. Nucleic Acids Res 25, 3389-3402.

Bauer, A. W., Kirby, W. M., Sherris, J. C. \& Turck, M. (1966). Antibiotic susceptibility testing by a standardized single disk method. Am J Clin Pathol 45, 493-496.

Dittmer, J. C. \& Lester, R. L. (1964). A simple, specific spray for the detection of phospholipids on thin-layer chromatograms. J Lipid Res 15, 126-127.

Dussault, H. P. (1955). An improved technique for staining red halophilic bacteria. J Bacteriol 70, 484-485.

Ezaki, T., Hashimoto, Y. \& Yabuuchi, E. (1989). Fluorometric deoxyribonucleic acid-deoxyribonucleic acid hybridization in microdilution wells as an alternative to membrane filter hybridization in which radioisotopes are used to determine genetic relatedness among bacterial strains. Int J Syst Bacteriol 39, 224-229.

Felsenstein, J. (1981). Evolutionary trees from DNA sequences: a maximum likelihood approach. J Mol Evol 17, 368-376.

Felsenstein, J. (2005). PHYLIP (phylogeny inference package), version 3.6. Distributed by the author. University of Washington, Seattle, USA.

Gerhardt, P., Murray, R. G. E., Wood, W. A. \& Krieg, N. R. (1994). Methods for General and Molecular Bacteriology. Washington, DC: American Society for Microbiology.

Gonzalez, J. M. \& Saiz-Jimenez, C. (2002). A fluorimetric method for the estimation of $\mathrm{G}+\mathrm{C}$ mol $\%$ content in microorganisms by thermal denaturation temperature. Environ Microbiol 4, 770-773.
Gutierrez, C. \& Gonzalez, C. (1972). Method for simultaneous detection of proteinase and esterase activities in extremely halophilic bacteria. Appl Microbiol 24, 516-517.

Kimura, M. (1980). A simple method for estimating evolutionary rates of base substitutions through comparative studies of nucleotide sequences. J Mol Evol 16, 111-120.

Kluge, A. G. \& Farris, J. S. (1969). Quantitative phyletics and the evolution of anurans. Syst Zool 18, 1-32.

Oren, A., Duker, S. \& Ritter, S. (1996). The polar lipid composition of Walsby's square bacterium. FEMS Microbiol Lett 138, 135-140.

Oren, A., Ventosa, A. \& Grant, W. D. (1997). Proposed minimal standards for description of new taxa in the order Halobacteriales. Int J Syst Bacteriol 47, 233-238.

Purdy, K. J., Cresswell-Maynard, T. D., Nedwell, D. B., McGenity, T. J., Grant, W. D., Timmis, K. N. \& Embley, T. M. (2004). Isolation of haloarchaea that grow at low salinities. Environ Microbiol 6, 591-595.

Roh, S. W. \& Bae, J. W. (2009). Halorubrum cibi sp. nov., an extremely halophilic archaeon from salt-fermented seafood. J Microbiol 47, 162166.

Roh, S. W., Nam, Y.-D., Chang, H.-W., Kim, K.-H., Lee, H.-J., Oh, H.-M. \& Bae, J.-W. (2007a). Natronococcus jeotgali sp. nov., a halophilic archaeon isolated from shrimp jeotgal, a traditional fermented seafood from Korea. Int J Syst Evol Microbiol 57, 2129-2131.

Roh, S. W., Nam, Y. D., Chang, H. W., Sung, Y., Kim, K. H., Oh, H. M. \& Bae, J. W. (2007b). Halalkalicoccus jeotgali sp. nov., a halophilic archaeon from shrimp jeotgal, a traditional Korean fermented seafood. Int J Syst Evol Microbiol 57, 2296-2298.

Roh, S. W., Sung, Y., Nam, Y. D., Chang, H. W., Kim, K. H., Yoon, J. H., Jeon, C. O., Oh, H. M. \& Bae, J. W. (2008). Arthrobacter soli sp. nov., a novel bacterium isolated from wastewater reservoir sediment. J Microbiol 46, 40-44.

Roh, S. W., Nam, Y.-D., Chang, H.-W., Kim, K.-H., Sung, Y., Kim, M.-S., Oh, H.-M. \& Bae, J.-W. (2009). Haloterrigena jeotgali sp. nov., an extremely halophilic archaeon from salt-fermented food. Int J Syst Evol Microbiol 59, 2359-2363.

Saitou, N. \& Nei, M. (1987). The neighbor-joining method: a new method for reconstructing phylogenetic trees. Mol Biol Evol 4, 406425.

Sambrook, J., Fritsch, E. F. \& Maniatis, T. (1989). Molecular Cloning: a Laboratory Manual, 2nd edn. Cold Spring Harbor, NY: Cold Spring Harbor Laboratory.

Savage, K. N., Krumholz, L. R., Oren, A. \& Elshahed, M. S. (2007). Haladaptatus paucihalophilus gen. nov., sp. nov., a halophilic archaeon isolated from a low-salt, sulfide-rich spring. Int J Syst Evol Microbiol 57, 19-24.

Sehgal, S. N. \& Gibbons, N. E. (1960). Effect of some metal ions on the growth of Halobacterium cutirubrum. Can J Microbiol 6, 165-169.

Tamura, K., Dudley, J., Nei, M. \& Kumar, S. (2007). MEGA4: molecular evolutionary genetics analysis (MEGA) software version 4.0. Mol Biol Evol 24, 1596-1599.

Wayne, L. G., Brenner, D. J., Colwell, R. R., Grimont, P. A. D., Kandler, O., Krichevsky, M. I., Moore, L. H., Moore, W. E. C., Murray, R. G. E. \& other authors (1987). International Committee on Systematic Bacteriology. Report of the ad hoc committee on reconciliation of approaches to bacterial systematics. Int J Syst Bacteriol 37, 463-464.

Xin, H., Itoh, T., Zhou, P., Suzuki, K., Kamekura, M. \& Nakase, T. (2000). Natrinema versiforme sp. nov., an extremely halophilic archaeon from Aibi salt lake, Xinjiang, China. Int J Syst Evol Microbiol 50, 1297-1303. 